\title{
VIETINIŲ ANESTETIKŲ ŠALUTINIS POVEIKIS - ALERGIJA AR KITAS NEPAGEIDAUJAMAS POVEIKIS
}

\author{
SANDRA RAGAIŠIENE், DOC. DR. BRIGITA ŠITKAUSKIENÉ \\ KMU PULMONOLOGIJOS IR IMUNOLOGIJOS KLINIKA
}

Reikšminiai žodžiai: vietinio poveikio anestetikas, alergija, nepageidaujamas poveikis.

Santrauka. Straipsnyje aptartas galimas vietinių anestetikų nepageidaujamas poveikis, kurį sunku atskirti nuo tikrosios alergijos. Vietinio anestetiko sukeltus simptomus reikètų laikyti vaisto nepageidaujamu toksiniu poveikiu. Kartu reikia ivertinti kitas galimas priežastis: paciento susijaudinimą, hiperventiliaciją, klajoklio nervo ir kraujagyslines reakcijas bei adrenalino, esančio kai kurių vietinių anestetikų tirpaluose, poveikį. Taip pat svarbu įsitikinti, ar pacientas nėra įsijautrinęs lateksui. Tikrąsias alergines reakcijas anestetikai sukelia labai retai - jos tesudaro 1 proc. visų nepageidaujamy šiu vaistų reakcijų. Gydytojams svarbu atskirti tikrosios alergijos ir kito nepageidaujamo poveikio simptomus ir skirti tinkamą gydymą. Pacientą, kuriam įtariama buvusi alerginè reakcija vietiniam anestetikui, reikètų siųsti pas alergologą. Alergijai patvirtinti paprastai atliekami odos ir didejjančių dozių provokaciniai mėginiai. Straipsnyje pateiktos alerginių reakcijų i vietinius anestetikus gydymo rekomendacijos.

1 lentelè. AMINOAMIDŲ GRUPĖS VIETINIŲ ANESTETIKŲ TIRPALAI, REGISTRUOTI LIETUVOJE

\begin{tabular}{lll}
\hline $\begin{array}{l}\text { Bendrinis } \\
\text { pavadinimas }\end{array}$ & Pavadinimas rinkoje & $\begin{array}{l}\text { Pagalbinės } \\
\text { medžiagos }\end{array}$ \\
\hline Lidokainas & $\begin{array}{l}\text { Lidokainas Sanitas } 20 \mathrm{mg} / \mathrm{ml} \\
\text { inj.tirp. }\end{array}$ & Na hidroksidas* \\
\hline & $\begin{array}{l}\text { Lidokaina hidrochlorids } 2 \\
\text { proc. }\end{array}$ & Na hidroksidas* \\
& $\begin{array}{l}\text { Xylonor } 3 \text { proc. } \\
\text { noradrenaline }\end{array}$ & $\begin{array}{l}\text { Na hidroksidas* } \\
\text { Noradrenalinas } \\
\text { Na metabisulfitas\# }\end{array}$ \\
\hline Artikainas & Ubistesin forte & $\begin{array}{l}\text { Na hidroksidas* } \\
\text { Adrenalinas } \\
\text { Na sulfitas\# }\end{array}$ \\
\hline Mepivakainas & Mepivastesin 3 proc. & \\
\hline & Scandonest 3 proc. plain & \\
\hline Bupivakainas & Bupivacain 0,5 proc. & \\
\hline & $\begin{array}{l}\text { Mercaine Spinal 0,5 proc. } \\
\text { Heavy }\end{array}$
\end{tabular}

Vietiniai anestetikai yra vaistai, mažinantys neurono membranos laidumą natrio jonams, blokuojantys pirminị nervinị impulsą bei jo plitimą nervinèmis skaidulomis, ir taip sukeliantys vietinę nejautrą.
Pagal cheminę struktūrą vietiniai anestetikai skirstomi $i$ aminoesterius ir aminoamidus. Be pagrindinès vaistinès medžiagos, vietinių anestetikų tirpaluose gali būti stabilizuojamųjų medžiagų, antioksidantų ir kitų papildomų medžiagų, pvz., adrenalino. Antioksidantai reikalingi preparatuose su adrenalinu, kadangi adrenalino stabilumui užtikrinti tokių tirpalų $\mathrm{pH}$ turi būti mažesnis. Tirpalų sudètyje esantis adrenalinas prailgina vietinių anestetikų veikimo trukmę - sukelia vazokonstrikciją ir sumažina absorbciją i sisteminę kraujotaką. Lietuvoje registruoti vietinių anestetikų tirpalai ir galimos jų pagalbinès medžiagos pateikiamos 1 lentelèje.

2001 m. "Pharmacotherapy“ nuorodose išvardytų dažniausiai vartojamų esterių ir amidu grupès vietinių anestetiku tirpalu sudètyje dar buvo nurodoma galima pagalbinė medžiaga metilparabenas. Jos pastaruoju metu dèl dažnėjančių nepageidaujamų reakcijų atsisakoma.

\section{KAIP ATSKIRTI ALERGIJĄ NUO KITO VAISTO NEPAGEIDAUJAMO POVEIKIO}

Pirmą kartą vietinių anestetikų sukelta alerginė reakcija literatūroje aprašyta $1920 \mathrm{~m}$. W. H. Mook aprašè stomatologui pasireiškusi kontaktini dermatitą. Gydytojas pacientu nejautrai sukelti naudodavo apotesiną 2008 / Nr. 2 (4) 
2 lentelè. DAŽNIAUSI VIETINIU ANESTETIKŲ NEPAGAIDAUJAMO/TOKSINIO POVEIKIO SIMPTOMAI

\begin{tabular}{|c|c|c|c|c|}
\hline \multirow[t]{2}{*}{ Vietinis } & \multicolumn{4}{|c|}{ Sisteminis } \\
\hline & CNS & $\begin{array}{l}\text { Širdies ir kraujagysliu } \\
\text { sistemos }\end{array}$ & Imuninès sistemos & Kiti \\
\hline $\begin{array}{l}\text { Parestezijos, kurios gali } \\
\text { būti ir negrịzztamos }\end{array}$ & $\begin{array}{l}\text { Pirmieji simptomai: } \\
\text { - galvos svaigimas } \\
\text { - regos ar klausos sutrikimai } \\
\text { (sunku fokusuoti žvilgsnị, } \\
\text { spengimas ausyse) } \\
\text { - dezorientacija } \\
\text { - mieguistumas }\end{array}$ & $\begin{array}{l}\text { Tiesiogiai: } \\
\text { - miokardo slopinimas } \\
\text { - neigiamas inotropinis } \\
\text { poveikis } \\
\text { - kardiotoksinis poveikis } \\
\text { něštumo metu }\end{array}$ & $\begin{array}{l}\text { I tipo alerginės reakcijos: } \\
\text { - dilgèlinė } \\
\text { - rinorèja } \\
\text { - angioedema } \\
\text { - dusulys } \\
\text { - tachikardija ir hipotenzija } \\
\text { - anafilaksinis šokas }\end{array}$ & $\begin{array}{l}\text { Methemoglobinemija: } \\
\text { - cianozé } \\
\text { - pilka odos spalva } \\
\text { - tachipnëja } \\
\text { - krūvio netoleravi- } \\
\text { mas ir nuovargis } \\
\text { - galvos svaigimas ir } \\
\text { alpimas }\end{array}$ \\
\hline \multirow[t]{2}{*}{ Užtrukusi nejautra } & $\begin{array}{l}\text { Kiti simptomai } \\
\text { (susiję su didesne vaisto doze): } \\
\text { - raumenų trūkčiojimai } \\
\text { - traukuliai } \\
\text { - sąmonès praradimas } \\
\text { - kvėpavimo slopinimas ir } \\
\text { sustojimas } \\
\text { - širdies ir kraujagyslių siste- } \\
\text { mos nepakankamumas }\end{array}$ & $\begin{array}{l}\text { Periferinis poveikis: } \\
\text { - mažos dozės sukelia krau- } \\
\text { jagyslių spazmą } \\
\text { - didelès dozès - vazodilata- } \\
\text { ciją ir hipotenziją }\end{array}$ & $\begin{array}{l}\text { IV tipo alerginès reakcijos: } \\
\text { - niežtintis išbèrimas, gali } \\
\text { būti su pūslelemis, injekcijos } \\
\text { vietoje (kontaktinis derma- } \\
\text { titas) }\end{array}$ & \\
\hline & & $\begin{array}{l}\text { Simptomai: } \\
\text { - krūtinės skausmas } \\
\text { - oro stygius } \\
\text { - dažnas širdies plakimas } \\
\text { - galvos svaigimas } \\
\text { - kraujospūdžio mažèjimas } \\
\text { - alpimas }\end{array}$ & & \\
\hline
\end{tabular}

(aminoesterių grupès vaistą). Jau nuo pat esterių pasirodymo vaistų rinkoje literatūroje kartas nuo karto buvo aprašomi nauji alerginių reakcijų $\mathfrak{i}$ vietinius anestetikus atvejai. Vis dèlto alergija nesudaro net 1 proc. visų šių vaistų sukeliamų šalutinių reakcijų. Taigi kyla klausimas, kodèl pacientai patys taip dažnai nurodo buvusią „alergiją anestetikams"?

Vietiniai anestetikai yra vieni iš dažniausiai skiriamų vaistų. Be jų šiuo metu neapsieinama stomatologinių, minimalių invazinių diagnostinių, chirurginių procedūrų metu. Apskaičiuota, kad odontologas vidutiniškai per metus suleidžia $1500-2000$ vietinių anestetiku injekcijų. Apie 6 proc. pacientu nepaaiškinamai bijo adatų. Adrenalino turinčių tirpalų injekcijos i kraujagyslingą burnos gleivinès audini dažnai pagreitina širdies plakimą. Tokị poveikị pacientai, o neretai ir gydytojai palaiko nepageidaujama alergine reakcija i vaistą. Lygiai taip pat ir kitoks nepageidaujamas poveikis, kuris pasitaiko labai dažnai, priskiriamas alerginèms reakcijoms.

Iš tiesų vietinių anestetikų sukeltos reakcijos galètų būti skirstomos $\mathrm{i}$ :

- nepageidaujamą/toksini vaisto poveikị;

- imuninę reakciją i vaistą - alergiją;

- organizmo reakciją i stresą, sukeliamą procedūros.

\section{Nepageidaujamas/toksinis vaisto poveikis}

Nepageidaujamą/toksinị vaisto poveikị dažniausiai lemia per didelè vietinio anestetiko koncentracija kraujo plazmoje. Tai ivyksta atsitiktinai suleidus tirpalo $\mathfrak{i}$ kraujagyslę ar i kraujagyslingą audinị, skyrus didelę vaisto dozę bei dèl sutrikusio vaisto pašalinimo iš organizmo (inkstų ar kepenų funkcijos nepakankamumas).
Toksinis poveikis dažnesnis pacientams, kuriems yra respiracinè acidozè, širdies laidumo sutrikimų ar kitų širdies ligų. Vietinių anestetikų toksinio poveikio rizika didesnè néščiosioms, vaikams bei senyviems pacientams, hipoksijos sąlygomis. Po vietinio anestetiko skyrimo atsiradusius simptomus visada pirmiausia reikètu vertinti kaip toksini vaisto poveikí.

Vietinių anestetikų toksinis poveikis gali būti vietinis ir sisteminis. Dažniausi simptomai esant nepageidaujamam/toksiniam poveikiui pateikiami 2 lentelèje.

Iprastas vietiniu anestetiku vietinis poveikis yra nutirpimas ir parestezija, tačiau didelès vaisto dozès gali sukelti negrižžtamą laidumo sutrikimą. Taip pat galimas periferinis neurotoksinis poveikis - išnykusios jutimų ir motorinès funkcijos ilgai nesugrižta.

Sisteminis nepageidaujamas vietinių anestetikų poveikis pirmiausia pasireiškia CNS bei širdies ir kraujagysliu sistemos simptomais. Pacientams, sergantiems širdies ir kraujagyslių ligomis, dèl vaisto tiesioginio slopinančio poveikio miokardui ir sukeliamos bradikardijos gali progresuoti širdies ir kraujagyslių nepakankamumas.

Kai kuriems anestetikams būdingas specifinis nepageidaujamas poveikis, pvz., benzokainui, labai retais atvejais ir lidokainui bei prilokainui - methemoglobinemija. Pacientas gali nieko nejusti, jei susidaręs methemoglobino kiekis yra mažas (1-3 proc.), tačiau didesnè jo koncentracija (10-40 proc.) sukelia simptomus (nurodyti 2 lenteleje).

Nepageidaujamų reakcijų riziką didina susijaudinimas, hiperventiliacija, nervo klajoklio ir kraujagyslinès reakcijos. Tik pavieniais atvejais (< 1 proc.) vietinis anestetikas gali sąlygoti intensyvesnę imunoglobulino $\mathrm{E}$ 
3 lentelè. MAŽIAUSIOS VIETINIŲ ANESTETIKŲ TOKSINÉS DOZĖS

\begin{tabular}{lc}
\hline Vaistas & Mažiausia toksinė doze் $(\mathbf{m g} / \mathbf{k g})$ \\
\hline Prokainas & 19,2 \\
\hline Tetrakainas & 2,5 \\
\hline Chloroprokainas & 22,8 \\
\hline Lidokainas & 6,4 \\
\hline Mepivakainas & 9,8 \\
\hline Bupivakainas & 1,6 \\
\hline Etidokainas & 3,4 \\
\hline
\end{tabular}

4 lentelè. LIETUVOJE REGISTRUOTI VIETINIAI ANESTETIKAI, SKIRTI ODOS IR GLEIVINIŲ NEJAUTRAI SUKELTI

\begin{tabular}{lll}
\hline $\begin{array}{l}\text { Bendrinis } \\
\text { pavadinimas }\end{array}$ & $\begin{array}{l}\text { Pavadinimas } \\
\text { rinkoje }\end{array}$ & Paskirtis \\
\hline $\begin{array}{l}\text { Benzokainas } \\
\text { (aminoesteris) }\end{array}$ & Menovazin & Odos tirpalas \\
\hline $\begin{array}{l}\text { Lidokainas } \\
\text { (aminoamidas) }\end{array}$ & $\begin{array}{l}\text { Lidocain 10 proc. } \\
\text { spray }\end{array}$ & $\begin{array}{l}\text { Purškalas odos ir } \\
\text { gleivinių nejautrai } \\
\text { sukelti }\end{array}$ \\
\cline { 2 - 3 } & Procto-Glyveno & $\begin{array}{l}\text { Tiesiosios žarnos } \\
\text { kremas/žvakutės }\end{array}$ \\
\cline { 2 - 3 } & Otipax & \begin{tabular}{l} 
Ausų lašai \\
\cline { 2 - 3 }
\end{tabular} \\
\cline { 2 - 3 } & Lidoposterin & $\begin{array}{l}\text { Tepalas nejautrai } \\
\text { sukelti }\end{array}$ \\
\cline { 2 - 3 } & Alvogyl & Dantenų pasta \\
\cline { 2 - 3 } & Cathejell L & Šlaplès gelis \\
\cline { 2 - 3 } & Caustinerf & Stomatologinė pasta \\
\hline
\end{tabular}

(IgE) gamybą - alerginę reakciją i vaistą. 3 lentelèje pateikiamos mažiausios vietinių anestetikų dozès, kurios gali sukeli nepageidaujamą toksinị poveikį.

\section{VIETINIAI ANESTETIKAI, SKIRIAMI GLEIVI- NIŲ IR ODOS NEJAUTRAI SUKELTI}

Vaistų rinkoje yra nemažai vietinių anestetikų preparatų, skirtų gleivinių nejautrai sukelti. Šių vaistų (pvz.: tetrakaino, benzokaino, lidokaino) nepageidaujamas poveikis dažniausiai atsiranda dèl susidariusios per didelès koncentracijos kraujo plazmoje, kai skiriama per daug vaisto. Viena iš priežasčių - vaisto patenka ant nubrozdintos ar kitaip sužalotos gleivinès. Tokiais atvejais pacientas gali jausti deginimą ar dilgčiojimą vaisto veikimo vietoje. Burnos gleivinès nejautrai sukelti skiriamas lidokainas gali sąlygoti sistemines toksines reakcijas, ypač vaikams, kai vaisto ant gleivinès purškiama kelis kartus. Sisteminès toksinès reakcijos pasireiškia CNS ir širdies bei kraujagyslių sistemos pažeidimais (pradžioje traukuliais, vèliau kvèpavimo sutrikimais, bradikardija, aritmijomis, hipotenzija, širdies ir kraujagysliu nepakankamumu, širdies sustojimu). Tirpalai su adrenalinu gali sukelti CNS stimuliuojanti poveikị, hipertenziją, tachikardiją ir miokardo išemiją. Specifiškesnis vietinių anestetiku poveikis gleivinèms ryklès reflekso slopinimas. 4 lenteleje nurodyti šios grupès preparatai, registruoti Lietuvoje.

\section{ALERGIJA VIETINIAMS ANESTETIKAMS}

Kaip minèta, tikrosios alerginès reakcijos ì vietinius anestetikus tesudaro 1 proc. visų nepageidaujamų šios grupès vaistų reakcijų. Manoma, kad alergines reakcijas lemia skilimo produktas, kuris atsiranda serumo pseudocholinesterazei skaldant aminoesterius, - paraaminobenzoinè rūgštis (PABA). PABA pasižymi dideliu antigeniškumu ir sukelia humoralinị imuninị atsaką antikūnų gamybą.

Alergija vietinių anestetikų tirpalams galima dèl šių priežasčių:

1. Alerginè reakcija ị veikliąją medžiagą - aminoesterị ar aminoamidą.

Vietiniai anestetikai yra mažos organinès molekulès (mažiau nei 300 daltonų), todèl jos per mažos, kad galètų būti antigeniškos, tačiau organizme prisijungusios audinių ar plazmos baltymus gali tapti haptenais.

Aminoesteriai yra PABA derivatai, dèl to galimos ūminès alerginès reakcijos. Alerginių reakcijų i̇ aminoamidus dažnumas yra daug mažesnis, kadangi jų apykaitos metu PABA nesigamina. Itin reti atvejai, kai pacientas yra alergiškas ir aminoesteriams, ir aminoamidams.

Benzokaino turi daugelis losjonų nuo saulès ir tepalụ, skirtų hemoroiniams mazgams gydyti. Nustatyta, kad iki 5 proc. žmonių odos reakcija gali būti teigiama dèl šiuc produktų naudojimo.

2. Alergija tirpalo stabilizuojamosioms medžiagoms ir antioksidantams.

Vietinių anestetikų tirpalų sudètyje gali būti metilparabeno, sulfitu (Na bisulfito, metabisulfito). Stabilizuojamosios medžiagos metilparabeno struktūra panaši PABA, todèl ji gali sąlygoti alerginę reakciją, kuri yra labai reta aminoamidu grupés vaistams. Metilparabeno neturi mepivakaino tirpalai, todèl šiuo atveju juos skirti saugiausia. Dauguma pacientų dar prieš pirmą vaisto injekciją susiduria su parabenų junginiais. Metilparabenuc ir propilparabenuc yra daugelio losjonų, kosmetikos priemoniu sudetyje, taip pat purškiama ant maisto produktų, kad prailgètų jų tinkamumo laikas. Pastebèta, kad apie 5 proc. pacientu būna teigiama odos reakcija ị sulfonamidus. Sulfonamidai yra struktūriniai PABA analogai. Šios medžiagos taip pat plačiai naudojamos ne tik vietinių anestetiku gamyboje. Sulfitų antioksidantų dedama ị vyną ir maistą, prailgina šių maisto produktų tinkamumo vartoti laiką. Antioksidantų dedama ị vietinių anestetikų tirpalus su adrenalinu ar levonordefrinu.

3. Alergija lateksui.

Atsiradus reakcijai po vietinio anestetiko injekcijos, visada reikètuc patikrinti dèl alergijos lateksui, kadangi dèl dažno kontakto su lateksinèmis pirštinėmis stomatologijos ir kitụ medicininių procedūrų metu, pacientas gali būti įsijautrinęs lateksui.

Alergija vienai iš vietinių anestetikų tirpalų sudedamajai medžiagai - adrenalinui - negalima. Tačiau adrenalinas gali sukelti tokius simptomus:

- dažną širdies plakimą;

- nekontroliuojamą drebulic; 
- šalto prakaito pylimą;

- dažną kvėpavimą ir dèl to galvos svaigimą, dilgčiojimą rankų ir kojų pirštuose ir lūpose.

Mažai tikètina, kad tirpalų sudètyje esantis adrenalinas sukels tokius simptomus, kadangi jo kiekis preparate daug mažesnis nei tas, kurị išskiria organizmas stresinès situacijos (procedūros) metu. Vis dėlto, atsitiktinai suleidus vaisto ì kraujagyslę, gali pradèti labai dažnai plakti širdis, todèl, prieš leidžiant vietinius anestetikus su adrenalinu, labai svarbu pacientą perspèti apie galimą širdies veiklos padažnẻjimą, kuris yra nepavojingas.

Alerginè reakcija ị vietini anestetiką gali būti dviejų tipu (pagal Gell ir Coombs klasifikaciją). I tipo alerginè reakcija pasireiškia dèl specifinio antigeno - anestetiko (dažniausiai kaip hapteno) ar tirpale esančios pagalbinès medžiagos. Šios reakcijos metu didèja IgE gamyba, stimuliuojami mastocitai, $\mathfrak{i}$ audinius gausiai išsiskiria bioaminų, dèl to pasireiškia būdingi simptomai. Alergijos simptomai paprastai prasideda per kelias minutes.

IV tipo reakcijos yra lèto tipo, nesusijusios su IgE gamyba ir bioaminų išskyrimu. Reakcija pasireiškia injekcijos vietoje po paros ar vèliau.

Dažniausia šiuc alerginių reakcijų klinikinè išraiška matyt 5 lentelèje.

Ką reikètų žinoti gydytojui, jei pacientas pamini prieš keletą metų buvusią reakciją i anestetikus. Anksčiau didžioji dalis anestetikų buvo esterių grupės, todèl alerginių reakcijų, nors ir retai, bet pasitaikydavo. Anksčiau gamintų anestetikų šiuo metu rinkoje nebèra. Dažnai vartotas novokainas buvo esteriu grupès. Pastaruoju metu esterių grupès vietiniai anestetikai skiriami odontologijoje kaip skausmą malšinantys tirpalai ir geliai (benzokainas). Kadangi ju nepatenka i kraujotaką, ir pavojingu reakciju paprastai nepasitaiko. Kita pagalbinè tirpalo medžiaga, kurios irgi atsisakoma, yra metilparabenas (vietinių anestetikuc preparatuose, kuriuos šiuo metu naudoja odontologai, jos nèra). Šių medžiagų, kaip minèta, yra vaistuose, kosmetikos priemonèse ir maisto produktuose, todèl jų sukeliamų alerginių reakcijų padaugèjo.

\section{ALERGIJOS VIETINIAMS ANESTETIKAMS TYRIMAI}

Viena iš pagrindinių kontraindikacijų skirti vietinị anestetiką - nustatyta alergija preparatui. Ittarus buvusią alerginę reakciją, būtina pacientą siųsti alergologo konsultacijos.

Literatūroje teigiama, kad nèra nè vieno 100 proc. patikimo tyrimo alergijai vietiniam anestetikui diagnozuoti. Alergologu susitarimuose nurodoma, kad auksinis standartas yra alerginiai odos dūrio (AODM) ir íodiniai mèginiai. 6 lentelèje nurodyti galimi tyrimai diagnozuoti alergiją vietiniam anestetikui.

AODM gali būti atliekamas ne anksčiau kaip praèjus 6 savaitèms po buvusios reakcijos. Jei tyrimas atliekamas anksčiau, didesnè klaidingai neigiamo rezultato tikimybè. Tokiu atveju vertinami tik teigiami rezultatai.
5 lentelè. ALERGINIU REAKCIJU IVIETINIUS ANESTETIKUS TIPAI IR DAŽNIAUSIA KLINIKINË IŠRAIŠKA

\begin{tabular}{ll}
\hline Alerginès reakcijos tipas & Klinikinė išraiška \\
\hline I tipas & $\begin{array}{l}\text { Dilgèlinè, rinorèja, angioedema, } \\
\text { dusulys, tachikardija, hipotenzi- } \\
\text { ja, anafilaksinis šokas }\end{array}$ \\
\hline IV tipas & $\begin{array}{l}\text { Kontaktinis dermatitas. Injekci- } \\
\text { jos vietoje atsiranda niežtintis iš- } \\
\text { bèrimas, gali būti su pūslelemis }\end{array}$ \\
\hline
\end{tabular}

6 lentelè. PAGRINDINIAITYRIMAI ALERGIJAI VIETINIAM ANESTETIKUI

NUSTATYTI (PAGAL JOINT COUNCIL OF ALLERGY, ASTHMA, AND IMMUNOLOGY (JCAAI) REKOMENDACIJAS)

\begin{tabular}{ll}
\hline In vivo & Alerginis odos dūrio mėginys \\
\cline { 2 - 2 } & \multicolumn{1}{l}{ Iodinis mėginys didejančiomis preparato dozėmis } \\
\cline { 2 - 2 } & Odos aplikacinis mėginys \\
\cline { 2 - 2 } In vitro & Provokacinis mėginys \\
\cline { 2 - 2 } & Limfocitų transformacijos mèginys \\
\cline { 2 - 2 } & Leukocitų histamino išskyrimo mėginys \\
\hline
\end{tabular}

Mèginys turi būti atliktas su vietiniu anestetiku, kurio tirpale nèra stabilizatoriu (metilparabeno). AODM atliekamas su neskiestu tirpalu. Labai svarbu mėgini atlikti su vietiniu anestetiku, kurio tirpalo sudètyje nèra adrenalino, kadangi galimos klaidingai neigiamos reakcijos. Kaip ir kitų iprastų mėginių atveju, būtina atlikti neigiamos (su skiedikliu) ir teigiamos kontrolès (su histamino tirpalu) tyrimus. Teigiama AODM reakcija vertinama, kai po 20 minučių atsiranda papulè, kurios skersmuo yra $3 \mathrm{~mm}$ ir didesnis nei neigiamos kontrolès ir toks pat ar didesnis nei pusè teigiamos kontrolès papulès skersmens. Jei šie mėginiai neigiami, atliekamas jodinis mèginys.

Iodinis méginys yra 100 kartų jautresnis nei AODM. Jis pradedamas vietinio anestetiko tirpalu, praskiestu santykiu 1:1000 (skiedžiama fiziologiniu tirpalu, kuriame yra 5 proc. fenolio). Esant neigiamai reakcijai, toliau kas 20 minučių švirkščiama 0,03-0,05 ml 10 kartų mažiau praskiesto tirpalo. Mažiausias ịodinių tirpalų skiedimo santykis - 1:10. Iodiniai mėginiai su grynu tirpalu neatliekami dèl galimų klaidingai teigiamų rezultatu. Teigiama įodinio méginio reakcija vertinama, kai po 20 minučiu atsiranda $8 \mathrm{~mm}$ ar didesnè papulè, kuri yra bent dvigubai didesnè nei odos pakilimas dèl injekcijos.

Pacientui svarbu atlikti tyrimus dèl galimo ịsijautrinimo lateksui. Standartiškai atliekami AODM su paruoštais komerciniais ekstraktais. Galima ištirti specifinius IgE lateksui.

Provokacinis méginys (anestetikams ar lateksui) atliekamas tik tuo atveju, kai AODM ir íodinis mèginiai yra neigiami. Provokacinių méginių metu gydytojo prižiūrimam pacientui suleidžiamas toks kiekis vaisto kaip per minimalias procedūras. Atliekant mėgini su vietiniu anestetiku, skiriama 0,5-1,0 ml neskiesto tirpalo, kurio sudètyje nèra adrenalino. Pacientas dèl anafilaksinès reakcijos stebimas 30 minučių. Jei tyrimo 
Kortikosteroidai

Adrenalinas

Antihistamininiai vaistai

\begin{tabular}{|l|l|l|}
\hline Lengva reakcija & Vidutinio sunkumo reakcija & Sunki reakcija \\
\hline
\end{tabular}

Pav. GYDYTI VARTOJAMI VAISTAI PAGAL ALERGINĖS REAKCIJOS SUNKUMA

metu jokių reakcijų nėra, galima teigti, jog ši vaistą pacientui skirti saugu. Atliekant provokacini mègini lateksui, pacientui 15 minučių užmaunama lateksinè pirštinè. Mèginys yra neigiamas, jei per 30 minučių toje vietoje neatsiranda dilgèlinès pobūdžio išbèrimo.

Jei pacientui reakcija ì vaistą injekcijos vietoje išryškejja po kelių valandų ar dienų, galima įtarti kontaktinị dermatitą. Tokiu atveju įsijautrinimas anestetikui patvirtinamas odos aplikaciniu méginiu. Galima naudoti standartinị TRUE testą, kurio sudètyje yra keliu anestetikų mišinys. Mišinys vadinamas „Caine Mix“, i jị ieina vienas aminoamidu ir du aminoesterių grupès anestetikai.

Leukocitų histamino mėginį rekomenduojama atlikti pacientams, kuriems anksčiau ittariamas alergenas nebuvo skirtas. Šis tyrimas yra papildomas greta AODM. In vitro méginiai nepatvirtina alerginès reakcijos dèl susidariusiu haptenu. RAST tyrimas specifiniams IgE vietiniams anestetikams neatliekamas. In vitro tyrimai rekomenduojami pacientams, kuriems buvusi sunki anafilaksinè reakcija.

\section{GYDYMAS BEI TINKAMO VIETINIO ANESTETIKO PARINKIMAS}

Itarus bet kokị nepageidaujamą vaistą poveikị, pirmiausia svarbu užtikrinti paciento gyvybines funkcijas, laiku pradèti simptomini gydymą ir užkirti kelią reakcijos progresavimui bei îvertinti kitus galimus priežastinius veiksnius.

Vietinio anestetiko sukeltos alerginès reakcijos gydymas priklauso nuo jos sunkumo (pav.).

Lengvai alerginei reakcijai slopinti skiriama klemastino $2 \mathrm{mg}$ i vieną ar gerti (suaugusiesiems) 0,025 $\mathrm{mg} / \mathrm{kg}$ (vaikams). Vidutinio sunkumo reakcijos atveju papildomai skiriama adrenalino s/c (1:1000). Kortikosteroidai (125 mg metilprednizolono i v. ar $60 \mathrm{mg}$ prednizolono gerti) būtini sunkios reakcijos (pvz.: kvèpavimo sutrikimai, hipotenzija) atveju.

Dèl nepageidaujamo/toksinio vaisto poveikio atsiradusių sutrikimu gydymas taip pat nèra specifinis. Iki šio nėra visuotinai priimtu CNS pažeidimų simptominio gydymo rekomendacijų. Paprastai traukuliams slopinti skiriama benzodiazepinų ir barbitūratų. Tokiu atveju griežtai draudžiama skirti fenitoino, kadangi jis veikia per tuos pačius natrio kanalus ir gali stiprinti toksinį vietinio anestetiko poveikị. Sumažèjęs arterinis kraujo spaudimas reguliuojamas skysčiu infuzijomis $i$ veną ir vazokonstriktoriais.

Jei itariama alergija kuriam nors vietiniam anestetikui, bet nèra galimybės jos patvirtinti tyrimais, pakartotinės nejautros atveju reikètų rinktis preparatą, kurio molekulinè struktūra kitokia. Pavyzdžiui, lidokainas savo struktūra panašiausias i prilokainą ir etidokainą, o mepivakainas i bupivakainą. Unikalios molekulinès struktūros yra tik artikainas. Atliekant odontologines procedūras, prieš vietinio anestetiko injekciją gleivinès nejautrai reikètų naudoti lidokaino tirpalą. Netinka benzokainas, nes jis gali didinti alerginès reakcijos riziką.

Vietinių anestetikų parinkimas kitos procedūros metu Jei pacientui nustatyta alergija:

- aminoesteriuc grupès vietiniam anestetikui, skirkite aminoamiduc grupès preparatą;

- amonoamidu grupès vietiniam anestetikui, skirkite aminoesteriú grupés preparatą;

- metilparabenui ar/ir aminoesteriams ir aminoamidams kartu, skirkite metilparabeno neturintị tirpalą;

- antioksidantams ar sulfitams, pasitikslinkite tirpalo sudedamąsias dalis.

\section{SIDE EFFECTS OF LOCAL ANESTHETICS - ALLERGY OR OTHER UNDESIRABLE EFFECTS}

SANDRA RAGAIŠIENÉ, BRIGITA ŠITKAUSKIENÉ
DEPARTMENT OF PULMONOLOGY AND IMMUNOLOGY
KAUNAS UNIVERSITY OF MEDICINE

Key words: local anestetic, alergy, undesirable, effect. Summary. The article reviews the possible undesirable effects of local and topically applied anesthetics, which can not be easily distinguished from true allergic reaction. After the administration of local anesthetic agents, new symptoms should be considered as a possible signs of drug adverse effect - toxicity. Adverse effects are usually caused by high plasma concentrations of the local anesthetic. Other causes and triggering factors should also be considered, such as anxiety, hyperventilation, vaso-vagal reactions, as well as reactions to epinephrine, which is frequently added to local anesthetic solutions. Because of common use of latex gloves during the medical procedures, the possibility of latex allergy should always be excluded. Hypersensitivity reactions to local anesthetics are extremely rare, they occur in less than 1 proc. of all reactions. True allergic reaction is usually due to preservative or antioxidant used in the local anesthetic solutions. Recognizing signs and symptoms of an allergy and other adverse effects to local anesthetics and administering emergency care in relation to the severity of the reaction are essential. The patient experienced adverse effect to local anesthetic should be referred to an allergist to elucidate a suspected allergy to used drug. Skin testing and incremental dose challenges can be performed if future local anesthesia is necessary. Recommendations concerning appropriate use of local anesthetics and alternative therapies in patients with documented local anesthetic allergies are given.

\section{LITERATŨRA}

1. Zamanian RT, Su M, Kapitanyan R, Olsson JK. Toxicity, local anesthetics. Emedicine, toxicology. updated March 2008

2. McLeod IK, Gallagher III DJ, Revis Jr DR, Seagle MB. Local Anesthetics. Emedicine, Pharmacology updated July 2008.

3. Phillips JF, Yates AB, Deshazo RD. Approach to patients with suspected hy persensitivity to local anesthetics. Am J Med Sci. Sep 2007;334(3):190-6.

4. Mertes PM, Laxenaire MC, Lienhart A, Aberer W, Ring J, Pichler WJ, Demoly $P$. Reducing the risk of anaphylaxis during anaesthesia: guidelines for clinical practice J Invest Allergol Clin Immunol. 2005;15(2):91-101.

Kiti literatūros šaltiniai - redakcijoje (iš viso 9). 